УДК 368.075.8:351.863:658/620.9

DOI: https://doi.org/10.37320/2415-3583/7.16

Мухін В.В.

здобувач,

Наиіональний інститут стратегічних досліджень

Письменна У.Є.

кандидат економічних наук, старший науковий співробітник, старший викладач, ДУ «Інститут економіки та прогнозування НАН України», НТУУ «Київський політехнічний інститут імені Ігоря Сікорського»

Лапко О.O.

доктор економічних наук, професор, професор, НТУУ «Київький політехнічний інститут імені Ігоря Сікорського»

\title{
РОЗВИТОК ІНТЕГРАЦІЇ РЕГІОНАЛЬНИХ ГАЗОВИХ РИНКІВ
}

У статті досліджено стан формування ринку природного газу в Украӥні та виявлено фактори, щчо стримують конвергениію украӥнського та європейського газових ринків. Проаналізовано питання створення в Украӥні міжрегіонального газового хабу та його значення для зосередження на території держави значних обсягів товарного природного газу, щзо є запорукою довгострокової енергетичної безпеки. Обтрунтовано, щзо важливим елементом реалізачії довгострокової політики досягнення загальної безпеки, енергетичної стабільності та забезпечення диверсифікації постачання енергетичних ресурсів в Європу є наявні ресурси створення $і$ розвитку транскордонних енергетичних мереж. Створення та розвиток інтерконекторів сприятиме підвищенню взаємодії між енергетичними ринками, задоволенню попиту, забезпеченню прийнятного рівня цін для споживачів.

Ключові слова: ринок природного газу; конвергениія енергетичних ринків; регіональний газовий ринок; транзит газу; газовий хаб; система підземного зберігання природного газу.

Постановка проблеми. Співробітництво країн Свропи у сфері енергетики грунтується на принципах забезпечення регіональної енергетичної безпеки, конкурентоспроможності та довготермінової стабільності, що є необхідними для регуляторної адаптації роботи та розвитку наявної енергетичної інфраструктури до ключових елементів acquis EC. Партнерство і спільна відповідальність у проведенні регуляторних реформ енергетики сприяє регіональному економічному зростанню, посиленню ринкової інтеграції країн Європи на основі відкритих, енергоефективних та конкурентоспроможних енергетичних секторів. Цілісне розуміння глобальної енергетичної безпеки з урахуванням принципів безпеки видобутку, торгівлі, транзиту, зберігання, використання (попиту), транспортування, постачання, передачі зокрема такого енергетичного ресурсу, як природний газ, визначається спільною зацікавленістю країн світу в їх надійному, екологічно та економічно прийнятному енергозабезпеченні. На роль і місце України у системі глобальної енергетичної безпеки значним чином впливає повнота реалізації іiі геополітичних переваг на пан'європейському енергетичному просторі.

Аналіз останніх досліджень і публікацій. Особливості та основні проблеми інтеграції регіональних газових ринків та розвитку регіональної системи колективної енергетичної безпеки розглядалися в роботах А. Полянської, В. Ліра,
Є. Боброва, І. Братшін, О. Дзьоби, І. Запухляк, Р. Подольця, Д. Прейгера, Л. Уніговського, Р. Юхимця, П. Хізера, С. Пірані та ін. Із поглибленням конвергенції ринків газу СС та України потребують подальшого дослідження напрями розвитку ринку природного газу в Україні як складової інтегрованого регіонального газового ринку.

Формулювання цілей статті. Важливим напрямом розвитку інтеграції ринків є сприяння транскордонній торгівлі та забезпечення ринкової ліквідності природного газу в СС. Метою статті $€$ аналіз стану формування ринку природного газу в Україні та виявлення факторів, що стримують конвергенцію українського та європейського газових ринків.

Виклад основного матеріалу. Важливим інструментом розвитку інтеграції ринків, сприяння транскордонній торгівлі та забезпечення ринкової ліквідності природного газу в ЄС є запровадження правил балансу газу в системах передачі. Створення і розвиток систем «вхід-вихід» (балансових зон), до яких застосовується конкретний балансовий режим (який може включати системи розподілу або їх частину), визначається Регламентом (СС) № 312/2014 про створення мережевого кодексу з газопостачання для мереж передачі. У 2017 р. континентальну частину газового ринку Свропи було розділено на 35 балансових зон. Кожна балансова зони Європи має розташовані на iii кордонах взаємопов'язані точки з'єднання 
Європейської мережі системних операторів передачі газу. Основні точки з'єднання Європейської мережі системних операторів передачі газу з газопроводами України наведено на рис. 1. Точки з'єднання енергосистем (транскордонних газопроводів) класифікуються максимальними технічними можливостями транспортування обсягів природного газу та доступними напрямами цих потоків природного газу.

На форму організації та розвиток континентальної торгівлі газом неминуче вплинули загрози економічній безпеці країн СС, які пов'язані 3 наступними бар'єрами для вільного потоку газу через точки між мережевої взаємодії (перехресні пункти з'єднання): торгові бар'єри (різниця у якості природного газу тощо); відсутність гармонізації в технічних, експлуатаційних і комунікаційних областях; витрати часу; негативний вплив диспропорцій в європейській системі транспортування газу. Знайдені базові механізми вирішення потенційних проблем континентального ринку газу гуртуються на балансуванні регіональних інтересів країн в європейській системі колективної економічної безпеки: єдина валюта; єдина армія; єдина транспортна система; єдина енергетична система; загальний міжрегіональний орган, який забезпечує компроміс між національними та загально-континентальними інтересами країн. Сприяння ефективному обміну газом 3 відмінними якісними характеристиками між різними мережами його передачі грунтується на прозорості співпраці операторів систем передачі та процесах збільшення рівня інтеграції газового ринку в рамках ЄС. 3 метою полегшення і стимулювання континентальної торгівлі природного газу та зміцнення співпраці між європейськими операторами системи його передачі, в 2015 р. було запроваджено стандарт EN16726: 2015 «Gas infrastructure - Quality of gas - Group Н». Стандарт EN16726 визначає вимоги до якості природного газу в загальноєвропейській системі його передачі. Також він встановлює параметри та їх обмеження для груп газів, що відносяться до категорії висококалорійного газу «Н».

У більшості європейських країн основною якісною характеристикою природного газу прийнято Індекс Воббе «англ. Wobbe Index або WI», який $є$ функцією калорійності та відносної густини газу. Індекс Воббе $є$ показником порівняння виробництва енергії при згорянні різного складу паливних газів, таких як природний газ, зріджений нафтовий газ (LPG) та ін. Він є основою для оцінки ефективності горіння газу та вимірюється в МДж на куб. м. Індекс Воббе використовується як головний критерій взаємозамінності природних газів, який визначається учасниками європейського газового ринку в умовах договорів, специфікаціях якості, фізико-хімічних показниках та інші характеристиках природного газу, що допускається до транспортування, зберігання, постачання, купівлі або продажу.

У системі ENTSOG характерні суттєві відмінності в вимогах національних стандартів країни членів $\mathrm{CC}$ до якості природного газу, його теплотворної здатності та компонентного складу. Спочатку в Європі сформувались дві групи мереж газопроводів: група для низькокалорійних сортів газу (L-gas), що надходили з родовищ Нідерландів; група для висококалорійних сортів газу (H-gas), які видобувались на континенті або надходили 3 Норвегії, Алжиру та Росії. 3 метою спрощення імпорту і торгівлі природним газом були прийняті відповідні специфікації для висококалорійного $\mathrm{H}$, низькокалорійного L i проміжного сорту Е зі значними діапазонами по нижчій теплоті згоряння та Індексу Воббе.

Через регіональні відмінності поставок газу та особливості роботи газотранспортних систем у країнах $\mathrm{CC}$, групи $\mathrm{H}$ газу не мають однаковий склад або схожі варіації в їх складі. У деяких регіонах ЄС використовується для висококалорійних груп Н газу більш високий Індекс Воббе, в той час як інші регіони - більш низький. Крім того, в деяких регіонах в Європи використовується відносно вузький діапазон значення Індексу Воббе, в той час як в інших фактичні значення діапазону Індексу Воббе значно ширші. Слід зазначити, що застосування вимог стандарту EN16726: 2015 для країн ЄС є добровільним. Також, зазначеним вище стандартом не регламентуються допустимі порогові значення Індексу Воббе. Однією з основних цілей цього стандарту $є$ визначення загального діапазону Індексу Воббе на внутрішньому ринку газу $\mathrm{CC}$, розвитку конкуренції та безпеки поставок газу, його вільного транспортування, закачування (відбору) з газосховищ, розподілу та використання. Наприклад, наведені у дослідженнях Енергетичного співтовариства та ENTSOG значення Індексу Воббе на внутрішньому ринку газу в Іта-

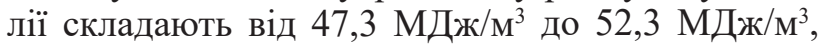

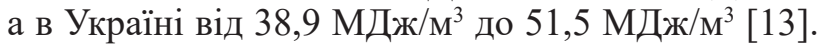
Крім того, для згладжування коливань попиту та параметрів природного газу, що поставляються по трубопроводам в періоди сезонного пікового споживання, в країнах світу застосовують різні добавки до його компонентного складу, у тому числі представлені у табл. 1.

Механізми максимально ефективного використання технічних потужностей, транскордонного обміну природним газом і сприяння інвестуванню у нову інфраструктуру мають бути: сумісними 3 системами доступу до мереж держав-членів Співтовариства; сумісними із ринковими механізмами (включаючи спот-ринки i центри торгівлі) та залишатись при цьому спроможними пристосовуватися до змінних ринкових умов. В континен- 


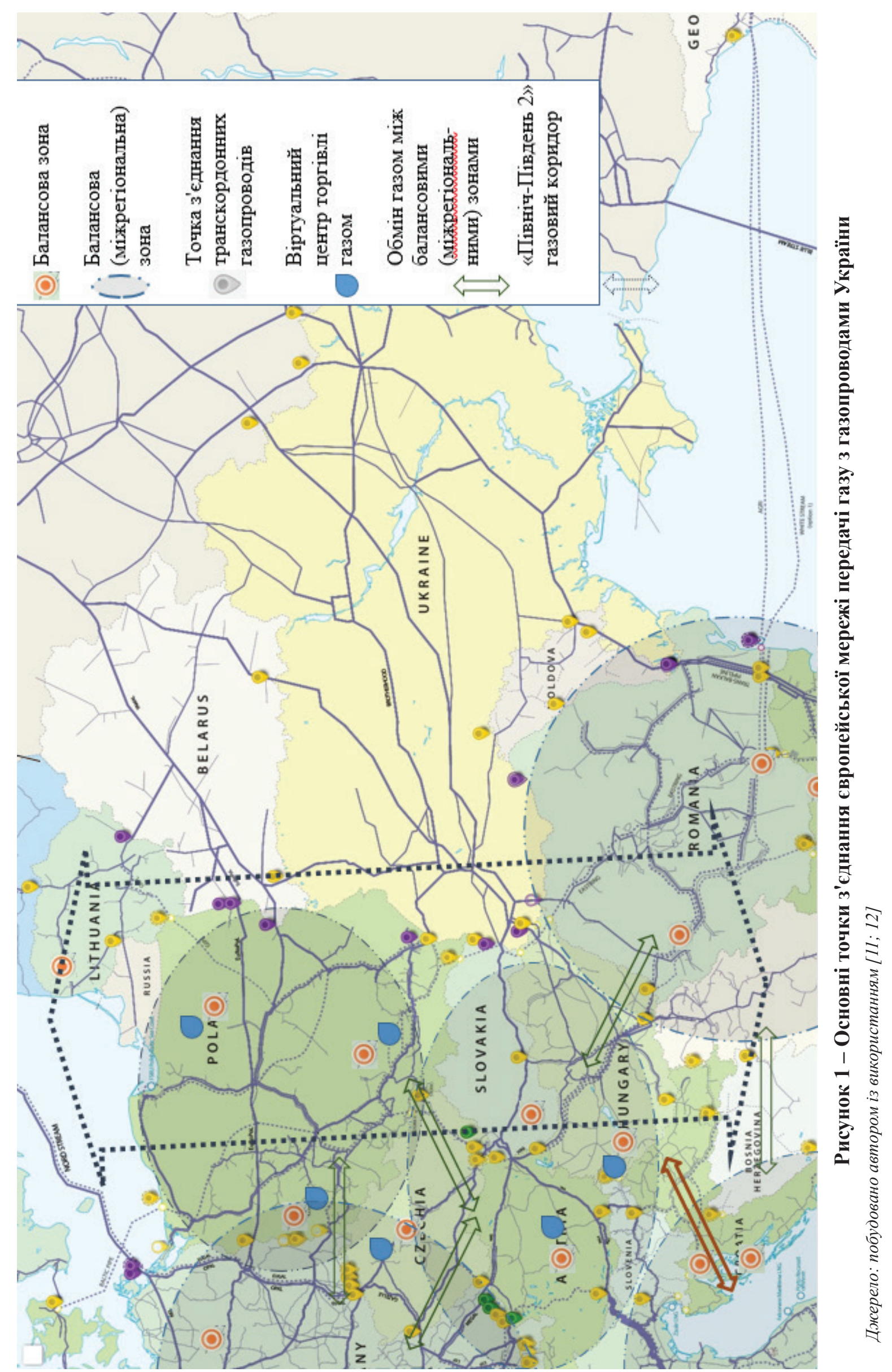


Таблиця 1 - Газові суміші, що поставляються по трубопроводам у періоди сезонного пікового споживання

\begin{tabular}{|c|c|c|}
\hline Найменування країни & Газ, газова суміш & Індекс Воббе, МДж/м $\mathbf{M}^{3}$ \\
\hline Фінляндія & пропан (56\%) - повітря (44 \%) & від 50,5 до 53,0 \\
\hline Німеччина & $\begin{array}{l}\text { скраплений вуглеводневий газ - } \\
\text { повітря та природний газ }\end{array}$ & $\begin{array}{l}>41,8 \text { (L-gas); } \\
>47,2 \text { (H-gas) }\end{array}$ \\
\hline Японія & $\begin{array}{l}\text { скраплений вуглеводневий газ - } \\
\text { повітря }\end{array}$ & від 62,0 до 62,8 \\
\hline Нідерланди & $\begin{array}{l}\text { скраплений вуглеводневий газ, газ } \\
\text { iз сховищ }\end{array}$ & від 43,4 до 44,4 \\
\hline Польща & $\begin{array}{l}\text { газ із сховищ, скраплений } \\
\text { вуглеводневий газ - повітря }\end{array}$ & - \\
\hline Швейцарія & пропан - повітря & - \\
\hline
\end{tabular}

Джерело: побудовано авторами із використанням [14]

тальній частині Свропи розташовуються ключові центри торгівлі газом, які розміщено на базі вузлів газотранспортної мережі або фізичних торгових точок сконцентрованих у регіоні. В роботі Інституту енергетики Південно-Східної Свропи [15] використано наступні підходи до класифікації європейських центрів торгівлі газом. Вузол газотранспортної мережі (газовий хаб) може бути фізичною точкою, у якій декілька трубопроводів збираються разом або віртуальною. Віртуальний вузол газотранспортної мережі забезпечує балансування газу в межах національних або транснаціональних системи газопроводів та може охоплювати міжрегіональну зону або всю країну. Віртуальний газовий хаб забезпечує широкому колу учасників ринку вхід/вихід газу в любій точці зони для його вільної торгівлі та не зобов'язує організовувати транспортування (збереження) газу. Альтернативний підхід Оксфордського інституту енергетичних досліджень до класифікації центрів торгівлі газом визначає наступні підходи [16]: Торгові центри забезпечують повноцінну та надійну роботу регіонального ринку природного газу, вони відкриті та доступні для широкого кола учасників (торгівельні майданчики досягли певного рівня зрілості для управління фінансовими ризиками певних газових портфелів); Транзитні центри - фізичні транзитні пункти, які забезпечують торгівлю газом переважно для сприяння його подальшого транзиту великими обсягам; Перехідні центри - засновані на віртуальних торгових точках, які не досягли зрілого ринкового рівня та визначають ціни на природний газ для своїх національних ринків.

Таким чином, у межах газових хабів ціни на природний газ також формуються на основі співвідношення між пропозицією та попитом. Обсяги торгів в основних європейських віртуальних центрах торгівлі природним газом (англ. Virtual Trading Point) протягом осінньо-зимового періоду 2015-2016 років залежали від рівня їхньої зрілості. Серед європейських центрів торгівлі при- родним газом найвищій рівень за обсягами торгівлі (їх коливаннями) протягом осінньо-зимового періоду досягнули National Balancing Point (NBP) та Dutch Title Transfer Facility (TTF). Обсяги максимальної торгівлі для NBP досягнули розміру більше 2300 ТВт*год/міс, а для ТTF склали майже 2200 ТВт*год/міс. Інші основні центри торгівлі природним газом знаходились на значно нижчому рівні за показниками середніх обсягів торгів між 75 ТВт*год/міс для Point d'Exchange de Gaz (PEG) та 213 ТВт*год/міс для Netconnect Germany (NCG). Німеччина, другий за величиною споживач газу в ЄC, має значний потенціал для створення великого центру ціноутворення на базі German GASPOOL (GPL) та Netconnect Germany (NCG). Франція також має потенціал та позитивні тенденції зростання обсягів торгівлі газом на базі French Point d'Exchange de Gaz Nord (PEG Nord) та Trading Region South. Бельгія, відкривши перший 3 континентальних центрів торгівлі газом Zeebrugge (ZB), сьогодні знаходиться у скрутному становищі, віддавши свою першість Нідерландському центру торгівлі газом - Dutch Title Transfer Facility (TTF). Важливо також відзначити розвиток на континентальному європейському ринку газу енергетичних бірж. Робота цих бірж сприяла зростанню обсягів торгівлі газом на регіональних ринках та закріпила за європейськими центрами торгівлі газом (рис. 2) ключову роль у визначені ринкової ціни на нього (англ. spot hub pricing).

Теоретичні підходи до розгляду специфічних характеристик формування цін на нафту i газ мають такі особливості, які не вкладаються в звичайні канони економічної теорії. Регіональні ринки газу набувають все більшого значення в забезпеченні прозорості процесів ціноутворення та конкуренції. В сфері теоретичних та історичних аспектів аналізу проблем безпеки виокремлюються механізми формування ціни газу (яким чином встановлюється ціна) та фундаментальні ринкові механізми (що визначають рівень ціни). До переліку основоположних принципів роботи 


\section{Вузол газотранспортної мережі (газовий хаб)}

\section{Енергетична біржа}

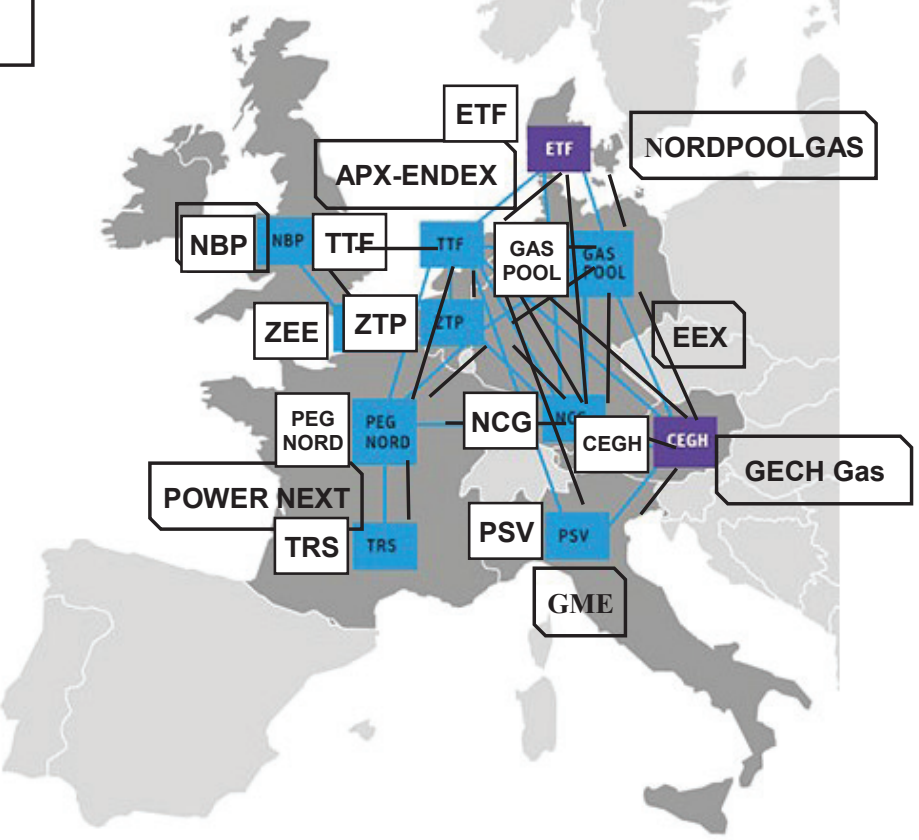

Рисунок 2 - Основні центри торгівлі природним газом в Свропі

Джерело: побудовано авторами із використанням [16]

ліквідних регіональних ринків природного газу не входять природні механізми економічної безпеки щодо забезпечення зниження ціни газу в умовах конкуренції або іiі утримання на низькому рівні. Економічні процеси на ринках газу континентальної Європи зменшують значення ціни нафти в загальній системи ціноутворення на газ, розширюють технічні можливості гнучкого транспортування та зберігання газу відповідно до цінових сигналів ринку. Трансформаційні процеси створення повністю конкурентного Єдиного європейського ринку природного газу використовують комерційні можливості різних джерел надходження газу, потужності міжрегіонального транзиту та зберігання газу. Поява нових фізичних або торгових вузлів газотранспортної мережі $€ \mathrm{C}$, пошук суб’єктами ринку нових комерційних можливостей стимулюватимуть торгівлю газом та подальший розвиток торгових майданчиків.

У середньостроковій перспективі механізм ціноутворення для довгострокових газових контрактах буде змушений враховувати ринкове формування ціни на основі маркерів вузлів газотранспортної мережі ЄС, забезпечувати баланс інтересів між безпекою попиту та безпекою постачання [16]. Газові хаби сприяють процесам біржової (спотової, ф'ючерсної) та позабіржової (форварди) торгівлі газом, значною мірою нівелюють ризики зміни цін, політичні або фінансові маніпуляції. Рівень ефективності торгівлі при- родним газом на базі інфраструктури газових хабів Європи обумовлюється наступними основними факторами: ліквідність; волатильність; анонімність; ринкова прозорість; обсяги торгівлі. Вузли газотранспортної мережі Європи відіграють ключову роль у забезпеченні безпеки постачання газу шляхом надання наступних основних видів енергетичних послуг: транспортування; зберігання; балансування у пікові періоди; передача прав власності; надання природного газу в кредит; обслуговування (скраплення, очищення тощо) [17].

У довгостроковій перспективі також буде збільшуватись значення газосховищ, оскільки природний газ стане в більшій мірі резервним паливом для підтримки розвитку ВДЕ в Європі. Швидкий розвиток відновлювальної енергетики та зростання нерівномірності споживання природного газу вірогідно у кінцевому рахунку перетворить природний газ на стратегічне резервне паливо.

Боротьба 3 енергетичною бідністю в світі сприяє розвитку міжнародного співробітництва в галузі вдосконалення світової структури енергетичної безпеки, енергетичних послуг, стабільності та конкурентоспроможності. Спільні інтереси країн у забезпеченні свого стійкого, безпечного та передбачуваного розвитку продовжують та активізують науково-практичний розгляд задач міжнародної кооперації в енергетиці. В тому числі дослідження у напрямках ринкової інтеграції, під- 
вищення ефективності світової структури попиту та пропозиції енергоресурсів. Багатобічні правила функціонування відкритих і ефективних енергетичних ринків забезпечують більш збалансовані та ефективні інструменти міжнародної співпраці, ніж ті, які породжуються двосторонніми угодами або ненормативними правовими засобами.

Досягнення прогресу у напрямку сталості та ринкової інтеграції ставлять перед країнами ЄC амбітні наміри розбудови більш стабільних, конкурентоспроможних та безпечних енергосистем [18]. Важливим елементом реалізації довгострокової політики досягнення загальної безпеки, енергетичної стабільності та забезпечення диверсифікації постачання енергетичних ресурсів в Європу $є$ наявні ресурси створення $\mathrm{i}$ розвитку транскордонних енергетичних мереж (далі - інтерконектори). Створення та розвиток таких інтерконекторів повинно допомогти підвищенню взаємодії між енергетичними ринками, сприяти задоволенню попиту, забезпечувати кращі ціни для клієнтів в Європі. Кожне міждержавне з'єднання мереж передачі джерел енергії передбачатиме наявність актуальної загальної оцінки потенційних ризиків і проблем щодо їх існування: довгостроковий аналіз соціально-економічної та екологічної вигоди та витрат; системний перегляд методологічних підходів до вимірювання взаємозв'язків потенційних переваг та витрат. $\mathrm{y}$ найближчому майбутньому науково-технічний розвиток та реалізація європейськими країнами політики забезпечення економічної безпеки держави (далі - ЕкБ) може істотно вплинути на енергетичну інфраструктуру континенту. Сталий розвиток генерації відновлювальних джерел енергії (далі - ВДЕ) в СС залежить не лише від використання переваг інтеграції національних ринків, торгівлі енергетичними матеріалами чи продуктами, включаючи всі енергетичні послуги. Збалансований розвиток нової генерації ВДЕ грунтується на створенні потужної мережі європейських інтерконекторів. Одночасно покриття за рахунок імпорту пікового внутрішнього споживання або тимчасового дефіциту потребує використання резервів енергетичної інфраструктури сусідніх країн.

ЕкБ грунтується на енергетичному базисі. Стан доступності за прийнятними цінами одного iз найважливіших енергоресурсів - природного газу дають змогу припустити, що невирішеними вважаються наступні проблеми ЦентральноСхідного газового регіону Свропи: гарантування енергетичної безпеки; конкурентоспроможність; коопераційні зав'язки; лібералізація та оздоровлення економік країн регіону. Національною програмою співробітництва Україна - НАТО також визначаються наступні пріоритети забезпечення енергетичної безпеки: інтеграція енергетичного сектору України до енергетичних ринків держав- членів $\mathrm{CC}$ та системи європейської енергетичної безпеки; будівництво (розширення) інтерконнекторів (магістральних газопроводів) між Україною і Польщею, Угорщиною, Словаччиною та Румунією; створення 3 державами-членами СС концентратора технічних потужностей для транспортування та зберігання природного газу (газового хабу); надійне енергозабезпечення та транзит енергоресурсів територією України. Сьогодні в більшій мірі об'єднаний газовий ринок Енергетичного Співтовариства є ініціатором змін, які далі закріплюються на законодавчому рівні СС. Проблеми входження України до об'єднаного газового ринку Енергетичного Співтовариства впливають на досягнення прогнозного рівня безпеки, стабільності та ефективності забезпечення країни енергоресурсами. Розвиток співробітництва, об'єднання європейських та українського ринків природного газу створюють необхідні передумови для еволюційного переходу енергетичного ринку України на європейські стандарти. Таким чином, спільні інтереси розвитку транс'європейської енергетичної інфраструктури надають змогу солідарного формування європейськими країнами в Україні Східно-Свропейського центру торгівлі природним газом. Єдиним ринковим механізмом довгострокового гарантування завантаження (існування) потужностей Єдиної газотранспортної системи України (далі - СГТСУ) є формування енергетичної та торговельної інфраструктури для нового міжнародного газового хабу. Перехід до лібералізації газового ринку України істотно залежить від забезпечення необхідної ліквідності операцій купівлі-продажу газу та досягнення певного рівня зрілості у біржовій торгівлі в межах нового газового хабу. 3 метою забезпечення прискореного розвитку нового Східно-Свропейського центру торгівлі газом, на думку автора протягом перехідного періоду доцільно використовувати європейські регіональні енергетичні біржі з хорошою репутацією.

Тарифи для користувачів ЄГТСУ мають бути прозорими, недискримінаційними, враховувати потребу у цілісності системи та відображати фактично понесені витрати, сприяти ефективній міжрегіональній торгівлі газом та конкуренції. Тарифи на доступ до мереж мають встановлюватися окремо на вхід та вихід у кожній фізичній або віртуальній точці входу/виходу систем транспортування, розподілу або зберігання природного газу. Новий віртуальний центр торгівлі газом в Україні має бути інтегрований з роботою основних віртуальних центрів торгівлі природним газом Центрально-Східного газового регіону Європи. Відмінності у витратах на транспортування (зберігання) природного газу або механізми балансування енергетичних систем не мають обмежувати вільний вибір джерел його постачання та пунктів 
призначення, погіршувати ліквідність ринку або спотворювати транспортування газу через балансові (міжрегіональні) зони.

Однією з ключових особливостей об'єднання внутрішнього ринку природного газу ЄС є різнорідність регіональних ринків країн. Параметри функціонування значною мірою лібералізованих ринків північно-західних регіонів відрізняються від ринків центральної, східної або південної частини Європи. Відчутні вигоди для європейських споживачів має забезпечити завершення до 2020 р. об'єднання регіональних ринків в межах газового коридору «Північ-Південь». Безпосередня прив’ язка «Північного потоку - 2» до транскордонної інфраструктури газового коридору «Північ-Південь» (German GASPOOL) матиме економічні та геополітичні важелі впливу з боку РФ на ціноутворення в Європі. Два споріднені північні потоки значною мірою будуть визначати стан монополізації регіонального ринку газу та формування індексів для довгострокових контрактів, впливати на процеси біржової (спотові та ф’ючерсні контракти) та позабіржової (форвардні контракти) торгівлі газом. Можливе поширення нових вимог Третьої енергетичного пакету на газопроводи 3 третіх країн в повній мірі не зможуть нівелювати безпрецедентні невизначеності будь якого лібералізованого ринку, політичні або фінансові маніпуляції 3 північними потоками. 3 метою поліпшення процесів об'єднання регіональних ринків країн Євросоюзу в єдиний конкурентний ринок, доцільно опрацювати на рівні ENTSOG альтернативний проект проведення «Північного потоку - 2» у Польщу (Гданськ або Калінінград).

Така прив'язка «Північного потоку - 2» до балансової зони Польщі матиме наступні стратегічні переваги. Створення на сході Свропи нового газового коридору «Північ-Південь 2» забезпечу- ватиме широкому колу учасників ринку вхід/вихід в любій точці балансових зон газу для його вільної торгівлі (збереження) та охоплювати наведені на рис. 1 балансові (міжрегіональні) зони наступних країн: Литви; Польщі; України; Словаччини; Угорщини; Румунії; Молдови; Болгарії; Греції.

Туреччина проводить амбітну енергетичну політику створення власного регіонального газового хабу, яка передбачає диверсифікацію поставок i конкуренцію між постачальниками російського, азербайджанського, іранського, ізраїльського та туркменського природного газу [19]. Країна реалізує проекти збільшення власних потужностей для підземного зберігання природного газу 33 млрд м м $^{3} 2017$ р. до 10 млрд м $^{3}$ у 2023 р. Слід відзначити, що ГТС Туреччини поки що не має достатньої інфраструктури для забезпечення зберігання та гнучкості транспортування природного газу, яка необхідна для перетворення регіонального ринку на центр торгівлі газом.

Висновки. Створення в Україні міжрегіонального газового хабу має важливе значення для зосередження на території держави значних обсягів товарного природного газу, що є запорукою довгострокової енергетичної безпеки. Незалежні постачальники природного газу також активно підтримують процеси створення в Україні газового хабу, який забезпечить розвиток сучасних інструментів міжрегіональної торгівлі природним газом. У цьому контексті надзвичайно важливе значення набуває надання можливості учасникам ринку зберігати газ в підземних сховищах України для його вільної міжрегіональної реалізації. Сучасний майданчик для відкритої торгівлі природним газом $€$ потужним економічним інструментом захисту України та попередження загроз реалізації нових проектів будівництва обхідних газових маршрутів для транспортування природного газу в країни СС із традиційних регіонів видобутку РФ.

\section{Список використаних джерел:}

1. South-North Corridor GRIP 2014-2023. URL: https://www.entsog.eu/public/uploads/files/publications/GRIPs/ (дата звернення: 21.12.2019).

2. ENTSOG transparency platform: Professional Data Warehouse System. URL: https://transparency.entsog.еu (дата звернення: 21.12.2019).

3. Wobbe Index and Gross Calorific Value in European networks, 2017. URL: https://www.entsog.eu/public/ (дата звернення: 21.12.2019).

4. Гнедова Л.А., Гриценко К.А., Лапушкин Н.А., Перетряхина В.Б., Федотов И.В. Анализ качества исходного сырья, применяемого для получения компримированного природного газа. Научно-технический сборник «Вести газовой науки». 2015. №1 (21).

5. The outlook for a natural gas trading hub in SE Europe, 2014. URL: http:/www.depa.gr/uploads/ (дата звернення: 21.12.2019).

6. Heather P. Continental European Gas Hubs: Are they fit for purpose? URL: http://www.oxfordenergy.org/wpcms/ (дата звернення: 21.12.2019).

7. Український газовий хаб - шанс для Європи. URL: http://dixigroup.org/storage/files/2016-12-19/ (дата звернення: 21.12.2019).

8. Towards a sustainable and integrated Europe. Report of the Commission Expert Group on electricity interconnection targets, 2017. URL: https://ec.europa.eu/energy/sites/ener/files/ (дата звернення: 21.12.2019).

9. Energy Policies of IEA Countries (Turkey 2016 Review). URL: https://www.iea.org/publications/freepublications/ (дата звернення: 21.12.2019). 


\section{References:}

1. South-North Corridor GRIP 2014-2023. Available at: https://www.entsog.eu/public/uploads/files/publications/GRIPs/ (accessed: 21.12.2019)

2. ENTSOG transparency platform: Professional Data Warehouse System. Available at: https://transparency.entsog.eu (accessed: 21.12.2019).

3. Wobbe Index and Gross Calorific Value in European networks, 2017. Available at: https://www.entsog.eu/public/ (accessed: 21.12.2019).

4. Gnedova, L. Grytsenko, K., Lapushkin, N., Peretryakhina, V., Fedotov, I. (2015). Analiz kachestva iskhodnogo syria, primenyaemogo dlya poluchenia komprimirovannogo prirodnogo gaza [The analysis of the quality of feedstock used to produce compressed natural gas]. Nauchno-technicheskiy sbornik "Vesti Gazovoy nauki" [Scientific and technical collection "Gas Science Letters"], no. 1 (21). (in Russian)

5. The outlook for a natural gas trading hub in SE Europe, 2014. Available at: http://www.depa.gr/uploads/ (accessed: 21.12.2019)

6. Heather P. Continental European Gas Hubs: Are they fit for purpose? Available at: http://www.oxfordenergy.org/wpcms/ (accessed: 21.12.2019).

7. Ukrainskiy gazovyi hab - shans dlya Evropy [Ukrainian Gas Hub is the European Chance]. Available at: http://dixigroup.org/storage/files/2016-12-19/ (дата звернення: 21.12.2019) (in Russian).

8. Towards a sustainable and integrated Europe. Report of the Commission Expert Group on electricity interconnection targets, 2017. Available at: https://ec.europa.eu/energy/sites/ener/files/ (accessed: 21.12.2019).

9. Energy Policies of IEA Countries (Turkey 2016 Review). Available at: https://www.iea.org/publications/freepublications/ (accessed: 21.12.2019).

Mukhin Volodymyr
National Institute of Strategic Studies

Pysmenna Uliana

State Institution «Institute of Economics and Forecasting of National Academy of Sciences of Ukraine», National Technical University of Ukraine «Igor Sikorsky Kyiv Polytechnic Institute»

Lapko Olena

National Technical University of Ukraine «Igor Sikorsky Kyiv Polytechnic Institute»

\section{THE DEVELOPMENT OF REGIONAL GAS MARKET INTEGRATION}

The article investigates the state of formation of the natural gas market in Ukraine and identifies the factors that hinder the convergence of Ukrainian and European gas markets. The issues of creation of inter-regional gas hub in Ukraine and its importance for concentration of large volumes of commercial natural gas, which is the key to long-term energy security, are analyzed. It is substantiated that the existing resources for the creation and development of crossborder energy networks are an important element in the implementation of a long-term policy of achieving overall security, energy stability and diversifying the supply of energy resources to Europe. The creation and development of interconnectors will help increase the interaction between energy markets, meet demand, and ensure an acceptable level of prices for consumers. The standards and key threats to the reliable and uninterrupted gas supply, including the determination of natural gas volumes to cover its deficit in case of difficult climatic conditions, unexpected demand fluctuations or gas supply disruptions, are the necessary prerequisite for preventing potential disruptions of gas markets, implementing the most cost-effective measures, coordinating in crisis situations. Common approaches to the issues of gas supply diversification and gas security challenges in the Central and Eastern European region are analyzed, as well as the problems of access to energy and its economically viable use, which are important factors in the reform of the energy sector in Ukraine. Stated is that the favorable geographical location, potential regional importance in ensuring the security and security of gas supply through the Ukrainian territory, the political and economic transformations in the world and reforming the structure of the European gas space are the main factors for Ukraine's transition to modern market models of functioning of the systems of economic security and energy efficiency. Particular attention is paid to the promotion of European energy standards of the energy security in the field of stabilization of the energy markets.

Key words: natural gas market; convergence of energy markets; regional gas market; gas transit; gas hub; natural gas underground storage system.

JEL classification: F15, L95. 